\title{
BMJ Open Impact of expansion of primary care in child health: a population-based panel study in municipalities in the Brazilian Amazon
}

\author{
Vânia Cristina Campelo Barroso Carneiro (D) , ${ }^{1}$ Paulo de Tarso Ribeiro de Oliveira, ${ }^{1}$ \\ Saul Rassy Carneiro, ${ }^{2}$ Marinalva Cardoso Maciel, ${ }^{3}$ Janari da Silva Pedroso (D) ${ }^{1}$
}

To cite: Carneiro VCCB, Ribeiro de Oliveira PdT, Rassy Carneiro S, et al. Impact of expansion of primary care in child health: a population-based panel study in municipalities in the Brazilian Amazon. BMJ Open 2022;12:e048897. doi:10.1136/ bmjopen-2021-048897

- Prepublication history for this paper is available online. To view these files, please visit the journal online (http://dx.doi. org/10.1136/bmjopen-2021048897).

Received 12 January 2021 Accepted 04 January 2022

D Check for updates

(c) Author(s) (or their employer(s)) 2022. Re-use permitted under CC BY-NC. No commercial re-use. See rights and permissions. Published by BMJ.

${ }^{1}$ PPGP, Universidade Federal do Pará, Belem, Brazil

${ }^{2}$ Hospital Universitário João de Barros Barreto - PPGCMH, UFPA, Belem, Brazil

${ }^{3}$ Faculty of Statistics, UFPA, Belem, Brazil

Correspondence to Dr Vânia Cristina Campelo Barroso Carneiro;

vania_barroso@yahoo.com.br

\section{ABSTRACT}

Objectives Considering the expansion of primary care in areas of difficult access in the Brazilian territory in recent decades, the aim of this study to evaluate the effect of the Family Health Strategy (FHS) expansion on hospitalisations due to ambulatory care-sensitive conditions (ACSCS) and mortality in children under 5 years of age in the state of Pará, Brazilian Amazon.

Methods A longitudinal analysis from 2008 to 2017 was conducted for data collected from the SUS's database (DATASUS) using panel regression methods to determine the association between the expansion FHS coverage, ACSC rate, under 5 mortality rate and child mortality rate in municipalities of the state of Pará.

Results There was an expansion of $40 \%$ of the population coverage of the FHS, in the same period there were 347 468.55 hospitalisations due to ASCSs of children under 5 years of age in the public health network in the state of Pará, which represented a reduction of almost $28 \%$ (p value $<0001$ ), and significant reduction of almost $57.67 \%$ in government hospital expenditures with hospitalisations between 2008 and 2017. In this period, there was also a significant decrease in the mortality rate in children under 5 years of age.

Conclusions Our findings reinforce the importance of the public health protection for the child population and the positive impacts of FHS in the state of Pará, in the Brazilian Amazon. The government actions aimed at reducing regional health disparities and the effort to strengthen primary care can improve health indicators of children and be an important strategy to developing countries.

\section{BACKGROUND}

In recent decades, Brazil has undergone profound changes in terms of socioeconomic development, income distribution, urbanisation and population health. At the end of the 1980 s, a national public and universal health system was established based on the characteristics of the population's geographical distribution, with primary care as the gateway to health services. ${ }^{12}$ Considering these parameters, the Unified Health System (SUS, for its acronym in Portuguese) instituted
Strengths and limitations of this study

- This study considers the panel data regression model from a representative survey of the Brazilian Amazon population that was used to assess the effect of the FHS on care ambulatory care-sensitive condition (ACSC) hospitalisations and mortality in children under 5 years of age.

- Although the use of primary care can be considered a proxy for 'realised' access to care, it remains only a proxy and does not consider unmet needs.

- This study only looks at access to primary care and does not explore other aspects of primary care quality that may be related to hospitalisation for ACSC, such as timeliness and effectiveness.

the creation of family health teams, which became the Family Health Strategy (FHS), whose main objective was to serve needy areas in the country. ${ }^{3}$

In this sense, the child population has always been the target of a large number of FHS health policies, programmes and goals, and children under 5 years of age are among the most vulnerable to social determinants of health and potentially sensitive to improvements in primary care. The reduction in mortality in this age group has always been considered an indicator of the quality of life of the population. ${ }^{4}$ However, despite advances in health over the years, the northern Brazil persisted with infant mortality rates of 21.8 per 1000 live births in 2014 , above the national average. This situation becomes even more worrying when considering the group of children under 1 year of age, due to the influence of factors associated with failures in prenatal care and the newborn, which could be avoided with the quality health assistance in primary care. ${ }^{56}$

The state of Pará is the most populous in northern Brazil and contains 26\% of the 
Amazon forest; a considerable portion of its population lives on the margin of rivers, which make up 20000 kilometres of hydrographic basin, or in municipalities with low human development indicators. ${ }^{78}$ In recent years, given the national policy of expanding healthcare to needy populations, this region received a significant increase in primary care, and the FHS population coverage reached $57 \%$ in the state of Pará in 2017; this expanded the supply of medical care, which included itinerant riverine health facilities in each territory municipality. ${ }^{9} 10$

Given the context of expanding primary care at the national level, the FHS is one of the largest global health programmes, responsible for providing services to 127 million Brazilian citizens. ${ }^{11}$ In this scenario, it would be expected that its action would produce effects on the quality of life of the population, in addition to impacting hospital admissions sensitive to primary care and child health because the FHS coverage is focused in more vulnerable areas and population groups, expands universal access to health services and ensures the continuity of medical care. The actions of the FHS provided by for the Brazilian legislation for the child population prioritise the follow-up of: pregnant women, newborns, children under 5 years, children with disabilities and children with hospital discharge, with timely medical care, diagnostic support, pharmaceutical assistance and immunisation from 0 to 19 years. ${ }^{12} 13$

Ambulatory care-sensitive conditions (ACSCs) is a widely used indicator to compare the availability and quality of outpatient care. Health systems that optimise access to primary care usually have positive impacts, especially on the child population because they represent an opportunity to develop preventive strategies aimed at reducing morbidity and mortality in this age group, and reduce hospital admissions and control government health costs through public policies related to child health. ${ }^{1415}$

The objective of this study was to evaluate the effect of the FHS expansion on hospitalisations due to ACSCs, its associated factors, and mortality in children under 5 years of age in the state of Pará from 2008 to 2017 in order to contribute to the definition of more appropriate interventions for child health in the Brazilian Amazon population.

\section{METHOD}

The expansion of the FHS, which is represented by the expansion of primary care population coverage, was explored to evaluate its possible effect on changes in hospitalisations due to primary care-sensitive conditions or preventable hospitalisations, municipal expenses with hospitalisation and mortality in children under 5 years of age in the municipalities of the state of Pará from 2008 to 2017.

Considering the relevance of morbidity and mortality indicators in childhood, it was decided to expand the analysis by highlighting the subsample of children under
1 year of age within the group of children under 5 years of age.

\section{Patient and public involvement}

In this longitudinal analysis data used are in the public domain were collected from the DATASUS (the SUS IT department) site of the Brazilian Ministry of Health, and population data were collected from the Brazilian Institute of Geography and Statistics (IBGE), according to the 2010 census, these data used do not require approval in ethics and research committees according to Brazilian law because they do not directly involve people and medical reports, being only a research with databases, whose information is aggregated, without the possibility of individual identification. ${ }^{16}$

\section{Source of data}

The FHS acts as a gateway to the SUS health services (gatekeeper) in Brazilian municipalities. ${ }^{17}$ In this study, population primary care coverage was defined as the number of established FHS teams, which was considered as a team consisting of a doctor, a nurse and three community health agents who were assigned to a population group of 3000 people living in a given territory. Ideally, it would be expected that the number of FHS teams would be sufficient to cover $100 \%$ of the population of a municipality. The study period was based on strategy expansion milestones considering the national health policy. ${ }^{3}$

The municipality was chosen as the study unit because it is the administrative level responsible for the implementation of the FHS and the lowest level for which data on exposure and results are available. Additionally, to control spatial heterogeneity, the municipalities were grouped into geographical mesoregions according to the IBGE classification ${ }^{18}$ as follows: Lower Amazonas, Marajó (M.), Metropolitan Belém, Northeast Pará, Southeast Pará (SE.P.) and Southwest Pará. This grouping allowed us to evaluate possible intra-state impacts on the evaluated indicators.

The ACSC rate aims to monitor the reduction in hospitalisations due to primary care-sensitive causes and has legal provision in Brazil since 2008 through a law published by the Ministry of Health. This is a set of diagnoses, based on the International Classification of Diseases-10, reflects the diversity of health and disease conditions in the national territory, applied to assess the performance of the health system in all age groups of the population assisted by primary care. ${ }^{19}$

The crude ACSH rates were calculated using spreadsheets and data on hospital morbidity and the population exposed to risk in each municipality studied. The main data source was the Hospital Information System of the SUS (SIH-SUS/DATASUS), which provided AIH-1 (hospital admission authorisation) files from which information was extracted on hospitalisations in 143 municipalities in the state of Pará, Brazil, calculated per 10000 inhabitants and compared with the non-ACSH rates in the selected geographical units, as described in detail 
previously. ${ }^{20}$ The reading of the AIH microdata considered 12 monthly files per year for each of the 143 municipalities from 2008 to 2017, totalling 693550 thousand admissions in the state of Pará in children under 5 years of age, of which $50.1 \%$ (347 468.55 thousand admissions) were ACSC in the evaluated period.

These data were combined for two age groups (younger than 5 years old and younger than 1-year-old) for each unit of analysis, and information on the number of hospitalisation and amount spent on ACSCs was obtained, which generated panels for the 143 municipalities in the period from 2008 to 2017. In addition, the data were analysed according to the 19 ACSC-related hospitalisation causes listed in the Brazilian legislation, according to municipality and year, and the number of hospitalisations was obtained for the 143 municipalities, for each disease group, in order to identify possible causes.

In the general database, the variable 'hospital expenditure' was also generated, which was obtained by the ratio between the amount paid for each individual hospitalisation and the number of hospitalisations in each municipality during the study period. After calculating the hospitalisation expenses per capita for each municipality, the percentage variation in the ratio between the amount paid with hospitalisation and the number of hospitalised children under 5 years and under 1 year in each municipality was determined, and the total costs for hospitalisation were determined in the state of Pará. Deflation techniques were applied according to the National Consumer Price Index (IPCA-IBGE), the official Brazilian inflation or deflation index, to evaluate inflation differences over the years of study.

The under 5 mortality rate (number of deaths in children under 5 year-old in a given location of residence and year/number of under 5 year-old of residents in the same location and year $\times 1000)$ and the child mortality rate (number of deaths in children younger than 1-year-old in a given location of residence and year/number of live births of residents in the same location and year $\times 1000$ ) was calculated with data obtained from the Mortality Information System (DATASUS) and Live Birth Information System (DATASUS).

\section{Statistical analysis}

For the exploratory analysis of the data, all the years included in the study were initially used to provide an overview and outline possible structural characteristics that occurred over time. Subsequently, for the years 2008 and subsequently, 2017, the mean and SD of the variables related to hospitalisation and spending on ACSCs for children under 5 years old and children under 1-year-old were calculated considering the data aggregated by municipality.

For comparison purposes, statistical analyses were performed for the total population of the municipalities at the beginning and end of the study period. Additionally, descriptive measures of under 5 mortality rate, child mortality rate and population coverage of the FHS were added for the years 2008 and 2017. The differences between the statistics at the beginning and end of the study period were tested with Student's t-test.

Exploratory data analysis was performed using modelling to provide a general overview of the study and to delineate possible structural characteristics of the crosssectional time-series data. Panel regression methods were used to assess the association between FHS coverage, ACSH rate, under 5 mortality rate and child mortality rate in the municipalities of Pará from 2008 to 2017.

The Hausman test was applied to assess unobserved effects, concluding that the random effects estimator would be the most suitable for the sample. The estimations were performed for the dependent variables 'rate of ACSH' and 'cost of ACSH'. For each dependent variable, two models were estimated:

Model 1: Only with 'FHS population coverage' as an explanatory variable;

Model 2: In addition to the 'FHS population coverage', control variable was added as a way to control the socioeconomic heterogeneity among the municipalities of Pará, which included information on the Municipal Health Fund (FMS, for its acronym in Portuguese) indicator, transfer of financial resources to health from the federal government to the municipalities to be allocated to the FHS and local hospitals, and mesoregion indicator variables to which the municipality belongs to capture some spatial heterogeneity.

An additional analysis explored the cause of ACSCs by using the classification of 19 causes listed in the ACSC Brazilian list (19). A proportion test was performed to compare the percentage in relation to the total of ACSC for each disease group. All statistical analyses were performed using Stata V.14.1 SE. Data and coding are available on request to the authors.

\section{RESULTS}

In the period from 2008 to 2017, there was an expansion of $40 \%$ of the population coverage of the FHS, in the same period there were 693550 hospitalisations of children under 5 years of age in the public health network in the state of Pará. Of these hospitalisations, $50.1 \%$ were related to ACSCs. Child hospitalisations in children under 5 years of age accounted for $25.2 \%$ of the total ACSCs in the period, of which $184430(53.1 \%)$ hospitalisations involved men and 163043 (46.9\%) involved women; the mean age of those hospitalised was 1.7 years old.

The rate of ACSCs in children under 5 years of age was higher than the rate of hospitalisation for other causes (non-ACSCs) in almost the entire study period. However, the considerable reduction in ACSC is highlighted in association with the expansion of population coverage of the FHS over the period evaluated, as shown in figure 1.

Table 1 shows the comparative population analysis of ACSCs in children younger than 5 years old and younger than 1-year-old in the state of Pará for 2008 and 2017. Among the 138178 hospitalisations in the state of Pará 

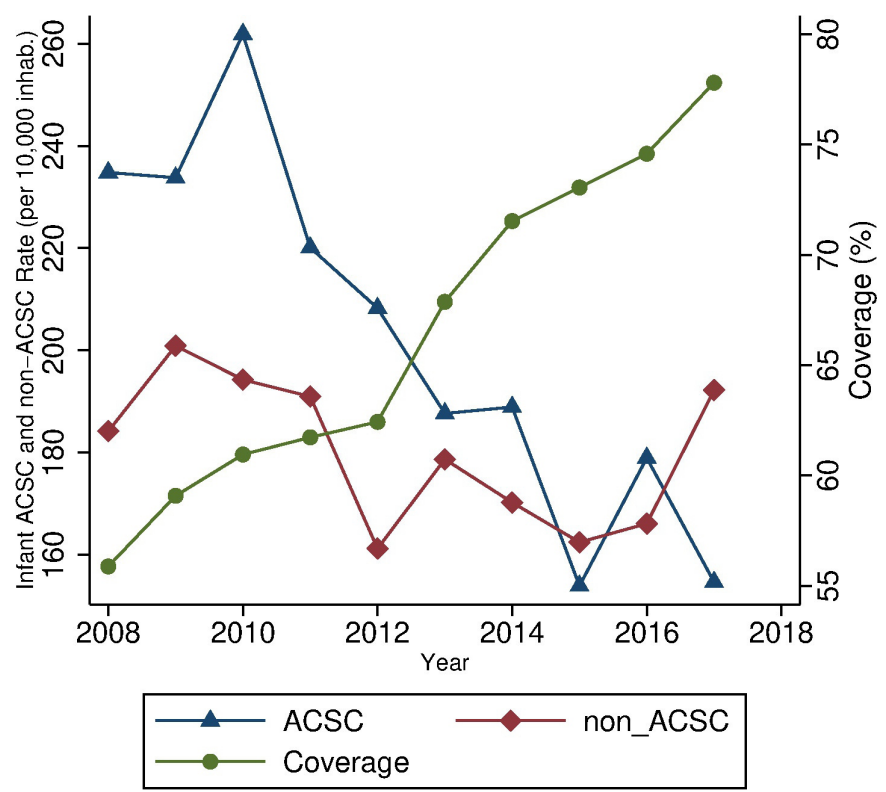

Figure 1 Infant Hospitalizations and Expansion of the Family Health Strategy between 2008 and 2017. Pará. ACSC, ambulatory care-sensitive condition.

by diseases related to ACSCs, 52.7\% (81 786 hospitalisations) were children younger than 5 years old hospitalised in 2008 and approximately $30 \%$ were under 1-year-old.

Comparing the respective proportions in 2017, there was a decrease in the proportion of ACSCs both for the total population and for the age groups investigated, and children under 1-year-old had a greater reduction in the proportion of ACSCs, which reached almost $28 \%$ between 2008 and 2017.

Table 2 shows the reduction in the ACSC mean rate between the beginning and end of the study period for the total population and age groups of children under 5 years old and 1-year-old. The most significant reduction was in the population of children under 5 years of age, with a decrease of more than $30 \%$ in preventable hospitalisations. In addition to the decrease in the ACSC rate, there was also a significant reduction of almost $57.67 \%$ in government hospital expenditures with hospitalisations, which represented savings of (Brazilian currency, Real $\mathrm{R} \$$ ) BRL 14953882.44 (4.5 million dollars) in the same evaluated period.

For children under 1 year of age, there was a slight increase in hospital expenditures; however, this increase is not statistically significant, and the SD is very large for this age group, which suggests possible differences in hospitalisation costs between municipalities, that is, some municipalities had cost reductions while others had increases.

In turn, the FHS population coverage, whose expansion was already shown in figure 1 , showed a statistically significant increase, especially at the end of the evaluated period.

In this period, there was also a significant decrease in the mortality rate in children under 5 years of age. Among the mesoregions of the state, the M. mesoregion showed the greatest reduction in mortality in children under 5 years of age (figure 2). The comparison between the average mortality rates by mesoregion showed a statistically significant difference at the level of $5 \%$ for the mesoregions of M. $(p=0037)$ and SE.P. $(p=0001)$.

The regression analysis of panel data for the crude model (Model 1, table 3) showed that the increase in FHS population coverage was directly related to the reduction in the ACSC rate in children under 5 years old in all regions of the state of Pará; even after the introduction of covariates (Model 2), the effect was still present and statistically significant.

Regarding the causes of ACSCs in children under 5 years of age, figure 3 shows that the main causes of hospitalisation were attributed to diseases related to infectious gastroenteritis (diarrhoea) and its complications. In 2008, this group of diseases accounted for $28720(66.7 \%)$ of the cases of ACSCs, and in 2017, there were 11639 (46.2\%) hospitalisations related to this group of diseases. This was the largest reduction $(30.7 \%)$ among the disease groups in the study period.

The other most representative groups were asthma, bacterial pneumonia and lung diseases (acute bronchitis). Asthma presented a 12\% reduction (5154 hospitalisations in 2008 compared with 3053 in 2017), and bacterial pneumonia presented a $10 \%$ reduction (4348 hospitalisations in 2008 compared with 2518 in 2017) in the number of hospitalisations over the study period. Regarding lung diseases, there was an increase in the number and percentage: from 1931 hospitalisations in $2008(4.5 \%)$ to 3093 hospitalisations in 2017 (12.3\%). Notably, the reduction in ACSCs in the nutritional deficiencies group decreased from 714 hospitalisations in $2008(1.7 \%)$ to 289 hospitalisations in $2017(1.1 \%)$.

Table 1 Number E share of hospitalisation ambulatory care-sensitive conditions. Pará. 2008/2017

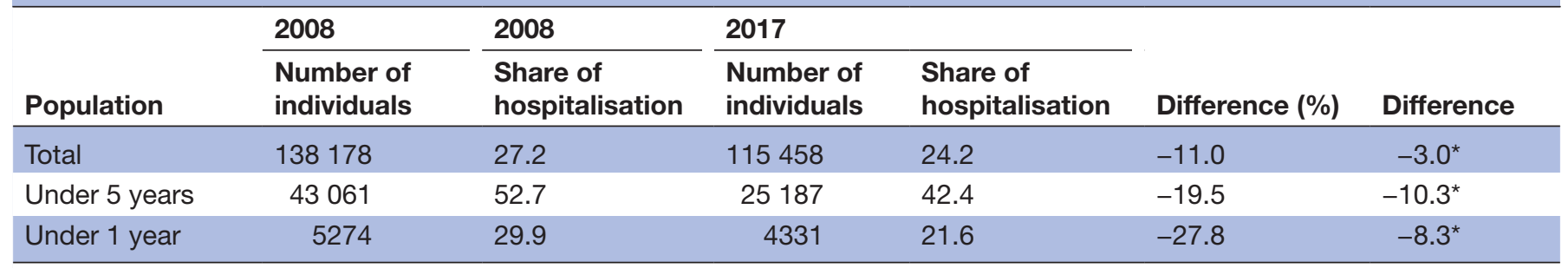

${ }^{*} \mathrm{p}<0.001$. 
Table 2 Hospitalisations and expenditure on ASCS, infant mortality rate and FHS coverage $(95 \% \mathrm{Cl})$

\begin{tabular}{|c|c|c|c|c|c|}
\hline Variable & Population & 2008 & 2017 & Difference (\%) & Difference \\
\hline \multirow[t]{2}{*}{$\begin{array}{l}\text { Hospitalisations for ACSC } \\
\text { (per } 10000 \text { population) }\end{array}$} & Total & $\begin{array}{l}213.41 \\
(187.98 \text { to } 238.84)\end{array}$ & $\begin{array}{l}171.75 \\
(149.39 \text { to } 194.11)\end{array}$ & -19.52 & $\begin{array}{l}-41.66^{\star \star} \\
(-75.55 \text { to }-7.77)\end{array}$ \\
\hline & Under 1 year & $\begin{array}{l}329.84 \\
(303.91 \text { to } 355.77)\end{array}$ & $\begin{array}{l}292.40 \\
(274.93 \text { to } 309.87)\end{array}$ & -36.66 & $\begin{array}{l}-37.44^{\star \star} \\
(-68.84 \text { to }-6.04)\end{array}$ \\
\hline \multirow{2}{*}{$\begin{array}{l}\text { Hospital expenditure on } \\
\text { ACSC (R } \$ \text { per capita) }\end{array}$} & Under 5 years & $\begin{array}{l}623.92 \\
(604.39 \text { to } 643.45)\end{array}$ & $\begin{array}{l}522.44 \\
(470.22 \text { to } 574.66)\end{array}$ & -16.26 & $\begin{array}{l}-101.48^{\star} \\
(-157.47 \text { to }-45.49)\end{array}$ \\
\hline & Under 1 year & $\begin{array}{l}760.29 \\
(649.40 \text { to } 871.18)\end{array}$ & $\begin{array}{l}793.85 \\
(682.21 \text { to } 905.39)\end{array}$ & 4.41 & $\begin{array}{l}33.56 \\
(-124.42 \text { to } 191.54)\end{array}$ \\
\hline $\begin{array}{l}\text { Mortality rate } \\
\text { (per } 1000 \text { live births) }\end{array}$ & Under 5 years & $\begin{array}{l}22.43 \\
(20.87 \text { to } 24.00)\end{array}$ & $\begin{array}{l}1.07 \\
(17.79 \text { to } 20.34)\end{array}$ & -14.98 & $\begin{array}{l}-3.36^{\star \star *} \\
(-5.38 \text { to }-1.36)\end{array}$ \\
\hline $\begin{array}{l}\text { FHS coverage } \% \\
\text { (teams per } 3450 \text { population) }\end{array}$ & Total & $\begin{array}{l}55.88 \\
(50.65 \text { to } 61.10)\end{array}$ & $\begin{array}{l}77.80 \\
(74.05 \text { to } 81.56)\end{array}$ & 39.23 & $\begin{array}{l}21.92^{\star} \\
(15.51 \text { to } 28.33)\end{array}$ \\
\hline
\end{tabular}

Values are mean $(95 \% \mathrm{Cl})$. Expenditures (\$) are constant BRL based on 2017 values.

${ }^{*} \mathrm{p}<0.001 ;{ }^{* *} \mathrm{p}<0.05 ;{ }^{* \star *} \mathrm{p}<0.01$

ACSC, ambulatory care-sensitive condition; BRL, Brazilian currency, Real R\$; FHS, Family Health Strategy.

In turn, there were increases in ACSCs in the kidney and urinary tract infection group (from $1.4 \%$ to $3.9 \%$ ), prenatal and delivery-related diseases (from $1.0 \%$ to $3.5 \%$ ), ear, nose and throat infections (from $0.8 \%$ to $4.3 \%$ ) and skin and subcutaneous tissue infections (from $0.7 \%$ to $3.6 \%$ ). The category 'Other' in figure 3 represents anaemia, diabetes mellitus, inflammatory diseases of female pelvic organs, cerebrovascular diseases, diseases preventable by immunisation and sensitive conditions, epilepsy, hypertension, heart failure, angina and gastrointestinal ulcer, which resulted in 557 hospitalisations in $2008(1.3 \%)$ and 711 hospitalisations in $2017(2.8 \%)$. The observed increase occurred mainly due to increases in epilepsy, hypertension and heart failure. Source: Executive Order № 221, 17 April 2008 (19).

\section{DISCUSSION}

This is a pioneering study that presents a detailed analysis of the relationship between primary care and important aspects of child health in municipalities that are part of the Brazilian Amazon. Using a panel of 143 municipalities in the state of Pará, it was possible to evaluate the significant expansion of FHS population coverage associated with a reduction in hospitalisation due to ACSC, hospital expenditures with these hospitalisations, and the reduction in mortality in children under 5 years of age in the studied region.

The results demonstrate the fundamental role that the FHS plays in the municipalities of the state of Pará, especially in reducing the causes of general morbidity and
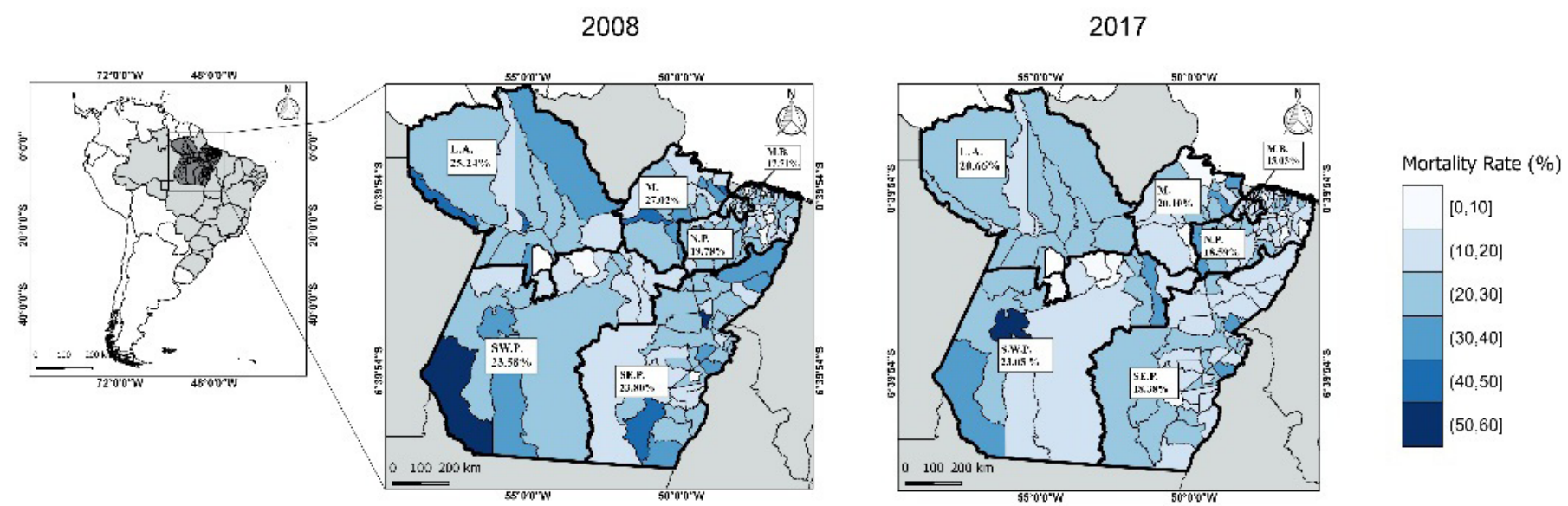

Figure 2 Mortality rate for children under 5 years. 2008/2017. Pará. 


\begin{tabular}{|c|c|c|}
\hline \multirow[b]{2}{*}{ Variables } & \multicolumn{2}{|l|}{ ACSC $(95 \% \mathrm{Cl})$} \\
\hline & Model 1 & Model 2 \\
\hline FHS coverage & $\begin{array}{l}-0.87(-1.20 \text { to } \\
-0.54)\end{array}$ & $-0.97(-1.30$ to -0.64$)$ \\
\hline FMS & & $-0.00(-0.00$ to -0.00$)$ \\
\hline \multicolumn{3}{|l|}{ Mesoregion* ${ }^{*}$} \\
\hline Lower Amazonas & & $-240.51(-356.36$ to -124.66$)$ \\
\hline Marajó & & $-256.99(-370.80$ to -143.17$)$ \\
\hline Northeast Para & & $-194.19(-291.53$ to -96.86$)$ \\
\hline Southeast Para & & $-100.68(-199.77$ to -1.60$)$ \\
\hline Southwest Para & & $-170.19(-286.24$ to -54.14$)$ \\
\hline
\end{tabular}

Source, SIH/DATASUS.

*The reference mesoregion is Metropolitan Belém. This is where the state capital is located.

ACSC, ambulatory care-sensitive condition; FHS, Family Health Strategy; FMS, Municipal Health Fund.

disease causes associated with poverty, such as malnutrition and diarrhoea, in children under 5 years of age. The primary care actions promoted in the FHS are developed by multidisciplinary teams, have a preventive purpose, and reduce risk factors through individualised care and health education. ${ }^{2122}$ These actions include quality and prenatal care, vaccination coverage, oral rehydration therapy and maternal and child guidance measures, which are effective strategies focused on the early detection of diseases and represent a determinant of child survival in developing countries. ${ }^{23} 24$

Vaccination is an integrated and routine action of primary healthcare services offered in the FHS in Brazil and has a great impact on the overall health of children. The Brazilian Ministry of Health recommends 95\% vaccination coverage for the basic regimen in children under 1-year-old, and such levels have been reached since $1998 .^{25} 26$

In the state of Pará, the results of our study confirm the benefits of expanding access to primary care health services, with preventive actions and guidance characteristic of the FHS for child health. We can assume that preventive actions such as the availability of vaccines in

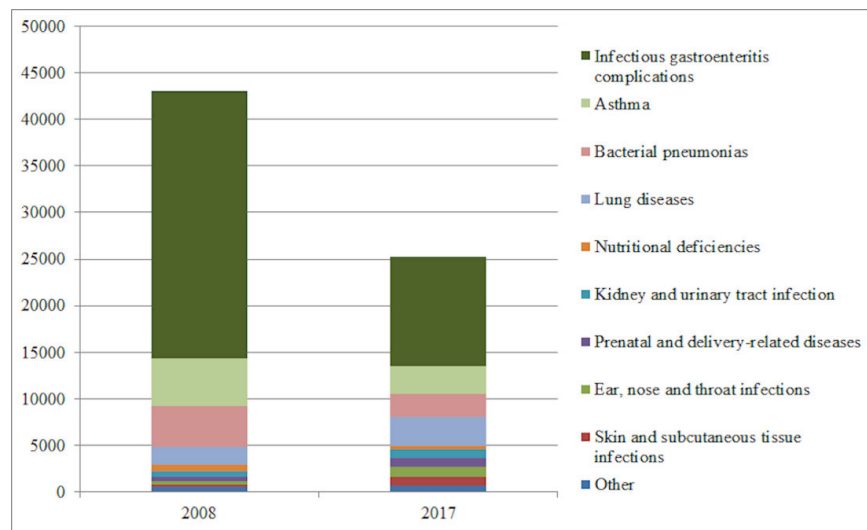

Figure 3 Ambulatory care-sensitive conditions in children under 5 years. 2008/2017. Pará. the childhood calendar against rotavirus, triple viral and pneumococcal and oral rehydration therapies for diarrhoea conditions, which are performed on primary care, were fundamental for the outcome found, mainly in the reduction of hospital admissions for diarrhoea, bacterial pneumonia and asthma, in addition to a more significant decrease in mortality in children under 1 year of age.

Brazil, historically characterised by inequities in health and wealth, is the country with the largest economy in Latin America and has experienced an important decline in child mortality in the last 30 years. Brazil achieved the reduction target established by the Millennium Development Goals before 2015, which lead to improvements in neonatal and child health. ${ }^{27}$ In this context, studies suggest that over the years, the municipalities that obtained the highest primary care expansion rates exhibited the highest reduction rates in child mortality and illness. ${ }^{28} 29$ After the expansion of the FHS population coverage, our study found that there was a reduction in illness in children younger than 5 years old throughout the study period. Thus, it should be considered that a health system with strong primary care may control most childhood diseases, with a consequent reduction in unnecessary hospitalisations.

According to Starfield, primary care does not exclude social and environmental health determinants but is able to minimise disparities and, thus, reduce regional inequities. ${ }^{30}$ This explanation is plausible for the state of Pará, which benefited from the expansion of the FHS in its municipalities, with improved health indicators for the child population. Although the state of Pará is a province rich in minerals in the Brazilian Amazon, $11 \%$ of its population (2 million people) lives in extreme poverty, only half of its population has a treated water supply, and more than $90 \%$ of its population does not have an adequate sewage system. ${ }^{31}$

A previous study conducted in the M. region showed the beneficial effects that population primary care coverage by the FHS provided to children in the Amazon region and its immense flexibility in adapting to the local context. ${ }^{32}$ Our study reinforced the benefits of the expansion of primary care in the same region, which had the highest decrease in mortality rates in children under 5 years old in the state of Pará.

We also observed an increase in the diagnosis of respiratory bronchitis (lung disease group) in the study period; lung diseases are frequent pathologies in childhood due to acute viral processes. In northern Brazil, there are risk factors that favour the onset of childhood respiratory diseases because of the socio-environmental conditions prevalent in the region, such as the high number of residents per household, low maternal education and low family income. ${ }^{33}$ Agglomeration is common among family members in the region, with high birth rates and precarious housing conditions, in which several inhabitants share the same room. ${ }^{34}$

The increase in the hospitalisation of children under 5 years old due to preventable pathologies such as urinary 
tract infections and ear, nose and throat infections, in addition to respiratory diseases (acute bronchitis), may also be due to extending the access of populations to FHS medical care, populations who had been deprived of this service for a long time. This allowed hospitalisations as a way to avoid major health problems; this also reduced hospitalisations for more advanced stage diseases, such as bacterial pneumonia, which represents a more severe evolution of lung disease in childhood. ${ }^{35}$

This study also found an increase in hospitalisations related to labour and puerperium. Research shows that although the country has advanced in prenatal care, the challenge in promoting the health of neonates and pregnant woman still persists as a consequence of a history of high rates of caesarean section and increased prematurity in recent years. ${ }^{3637}$ The increased incidence of congenital syphilis and the advent of Zika virus infection, which are realities in the Amazon region, are worrisome factors. ${ }^{38}$ The current challenge is the qualification and intensification of primary care actions focused on promoting the health of the pregnant woman and the fetus, ensuring a timely diagnosis and intervention for the prevention of prematurity, and encouraging humanised delivery education practices in the FHS.

Preventable hospitalisations represent a considerable financial impact on the management of resources allocated to the SUS and unnecessarily burden the health system. Finding a balance between primary care and hospital care has been a proposal to circumvent public spending and optimise the service to the population in the country. ${ }^{39}$ Our study showed a significant reduction of more than $57 \%$ in hospital expenses, which represented a savings of 4.5 million dollars to the state coffers regarding the hospitalisation of children under 5 years old in 2017. This corroborates the importance of preventive measures and longitudinal monitoring provided by the FHS so that hospitals can direct resources to secondary and tertiary care, which emphasises the fundamental role of primary healthcare in the context of government public policies.

Among the limitations of our study, we report those inherent to the methodology adopted, in which the use of administrative data are susceptible to notification errors or possible failures in information processing. For this purpose, a wide range of robustness tests was used to increase the quality of the results presented. In addition, the analysis of spending in historical series has limitations due to inflationary variations and other economic characteristics over time. In this case, the correction according to an economic index (IPCA/IBGE) was chosen to minimise this problem and facilitate comparisons. The ACSC causes defined in Brazilian legislation are not specified according to age. It should be noted that the data presented here were restricted to the evaluation of the public health system.

The findings were able to demonstrate that the expansion of primary healthcare has the potential to act on social determinants of health, with preventive and continued care actions and can substantially reduce illness and mortality in children under 5 years of age, especially in vulnerable populations and those living in remote locations of Brazilian municipalities, as in the state of Pará. However, despite the advances in health, the severe economic crisis that Brazil has faced since 2015 has caused the Brazilian government to adopt economic austerity measures that included budget cuts for social programmes, which affect the FHS. ${ }^{40} 41$ Such measures impacted the poorest municipalities in the country, increasing inequalities in child health and undermining the important achievements in health in recent years.

\section{CONCLUSIONS}

Our findings reinforce the importance of the public health protection for the child population and the positive impacts of FHS in the state of Pará, in the Brazilian Amazon. The government actions aimed at reducing regional health disparities and the effort to strengthen primary care can improve health indicators of children and be an important strategy to developing countries. Future evaluations that address the dynamic performance of primary care and its complex inter-relationship with the determinants of childhood illness will help corroborate the impact of the findings presented here.

Acknowledgements Universidade Federal do Pará - Pró - Reitoria de Pesquisa e Pós - Graduação. Conselho Nacional de Desenvolvimento Científico e Tecnológico.

Contributors The authors performed the following activities in the research: VCCBC - guarantor, research, data analysis, writing, review and submission. PdTRd0 - review, analysis, guidance and coordination of the research. SRCreview, analysis, submission and editing of the manuscript. MCM-statistical analysis, editing, figures and tables, data analysis and review. JdSP-review, analysis, guidance and coordination of the research.

Funding The authors have not declared a specific grant for this research from any funding agency in the public, commercial or not-for-profit sectors.

Map disclaimer The depiction of boundaries on the map(s) in this article does not imply the expression of any opinion whatsoever on the part of BMJ (or any member of its group) concerning the legal status of any country, territory, jurisdiction or area or of its authorities. The map(s) are provided without any warranty of any kind, either express or implied.

Competing interests None declared.

Patient and public involvement Patients and/or the public were not involved in the design, or conduct, or reporting, or dissemination plans of this research.

Patient consent for publication Not applicable.

Ethics approval This study does not involve human participants.

Provenance and peer review Not commissioned; externally peer reviewed.

Data availability statement All data relevant to the study are included in the article.

Open access This is an open access article distributed in accordance with the Creative Commons Attribution Non Commercial (CC BY-NC 4.0) license, which permits others to distribute, remix, adapt, build upon this work non-commercially, and license their derivative works on different terms, provided the original work is properly cited, appropriate credit is given, any changes made indicated, and the use is non-commercial. See: http://creativecommons.org/licenses/by-nc/4.0/.

ORCID iDs

Vânia Cristina Campelo Barroso Carneiro http://orcid.org/0000-0001-7277-4652 Janari da Silva Pedroso http://orcid.org/0000-0001-7602-834X 


\section{REFERENCES}

1 Macinko J, Harris MJ. Brazil's family health strategy--delivering community-based primary care in a universal health system. $N$ Engl J Med 2015;372:2177-81.

2 Viacava F, Oliveira RADde, Carvalho CdeC, et al. SUS: supply, access to and use of health services over the last 30 years. Cien Saude Colet 2018;23:1751-62.

3 BRASIL. Ministério dA Saúde. Política Nacional de Atenção Básica, 2007.

4 Velho P. Mortalidade Infantil NOS Últimos Quinquênios. child mortality in the last five-year periods in the city of. $J$ Hum Growth Dev 2014;24:86-92.

5 Queiroz F, Amaral C, Prado P. Mortality, evitability and basic causes of seath in a state of the brasilian Amazon. Rev Pesq Saude 2014;15:290-5.

6 BRASIL. Ministério dA Saúde. Pactos Pela redução dA Mortalidade Infantil no Nordeste E Amazônia legal Infantil no Nordeste E Amazônia legal 2009-2010. $1^{\circ}$ edição, 2010.

7 Governo do Estado do Pará. Plano Estadual de Saúde. Secr. Espec: Saúde Pública, 2016-2019: 1-258.

8 Burkhard B. ECOSYSTEM SERVICES - BRIDGING ECOLOGY, ECONOMY AND THE SOCIAL SCIENCES Special Issue of Ecological Complexity Guest Editors : Ecol Complex 2008;:2008-9. 9 e-Gestor AB. 10 BRASIL: Ministério da Saúde.

9 e-Gestor ab. Available: https://egestorab.saude.gov.br/paginas/ acessoPublico/relatorios/relHistoricoCoberturaAB.xhtml;jsessionid= OEMAuzZyF6JAQc31wxLb9pHd [Accessed2 July 2020].

10 BRASIL. Ministério dA Saúde. Available: http://bvsms.saude.gov.br/ bvs/saudelegis/gm/2014/prt0837_09_05_2014.html [Accessed 2 July 2020].

11 Pinto LF, Giovanella L. The family health strategy: expanding access and reducing hospitalizations due to ambulatory care sensitive conditions (ACSC). Cienc e Saude Coletiva 2018;23:1903-13.

12 Rasella D, Aquino R, Barreto ML. Impact of the family health program on the quality of vital information and reduction of child unattended deaths in Brazil: an ecological longitudinal study. BMC Public Health 2010;10:380.

13 Macinko J, de Oliveira VB, Turci MA, et al. The influence of primary care and hospital supply on ambulatory care-sensitive hospitalizations among adults in Brazil, 1999-2007. Am J Public Health 2011;101:1963-70.

14 Alfradique ME, Bonolo PDF, Dourado I. Ambulatory care sensitive hospitalizations: elaboration of Brazilian list as a tool for measuring health system performance (project ICSAP-Brazil). Cad saude publica / Minist da Saude, Fund Oswaldo Cruz, Esc Nac Saude Publica 2009;25:1337-49.

15 Pinto Junior EP. Costa L de Q, de Oliveira SMA, et al. expenditure trends in ambulatory care sensitive conditions in the under-fives in bahia, Brazil. Cienc e Saude Coletiva 2018;23:4331-8.

16 Demogr C, Estaduais S, Proje A. Projeção da População do Brasil por sexo e idade simples : 2000-2060 Notas Técnicas Origem dos dados Descrição das variáveis disponíveis para tabulação Idade e Faixa Etária 2010.

17 Brasil. Política Nacional de Atençao Básica, 2012.

18 Instituto Brasileiro de Geografia e Estatistica. Uso da terra no Estado do Pará : relatório técnico, 2013. Available: https://biblioteca.ibge. gov.br

19 Ministério da Saúde. PORTARIA N O 221, de 17 de ABRIL de 2008. D. of. dA República fed. do Bras, 2008.

20 Campelo Barroso Carneiro VC, Ribeiro de Oliveira PdeT, Rassy Carneiro S, et al. Evidence of the effect of primary care expansion on hospitalizations: panel analysis of 143 municipalities in the Brazilian Amazon. PLoS One 2021;16:e0248823.
21 Aquino R, de Oliveira NF, Barreto ML. Impact of the family health program on infant mortality in Brazilian municipalities. Am J Public Health 2009;99:87-93.

22 Mullachery P, Silver D, Macinko J. Changes in health care inequity in Brazil between 2008 and 2013. Int J Equity Health 2016;15:1-12.

23 Macinko J, Guanais FC, de Fátima M, et al. Evaluation of the impact of the family health program on infant mortality in Brazil, 1990-2002. $J$ Epidemiol Community Health 2006;60:13-19.

24 Campos ACV, Borges CM, Vargas AMD, et al. Social and health indicators as a measure of access to primary heathcare in Brazil. Cien Saude Colet 2011;16:4349-55.

25 Wang $\mathrm{H}$, Liddell CA, Coates MM, et al. Global, regional, and national levels of neonatal, infant, and under-5 mortality during 1990-2013: a systematic analysis for the global burden of disease study 2013. Lancet 2014;384:957-79.

26 Rasella D, Aquino R, Barreto ML. Reducing childhood mortality from diarrhea and lower respiratory tract infections in Brazil. Pediatrics 2010;126:e534-40.

27 Barros FC, Matijasevích A, Requejo JH, et al. Recent trends in maternal, newborn, and child health in Brazil: progress toward millennium development goals 4 and 5. Am J Public Health 2010;100:1877-89.

28 Guanais FC, Macinko J. The health effects of decentralizing primary care in Brazil. Health Aff 2009;28:1127-35.

29 França EB, Lansky S, Rego MAS. Leading causes of child mortality in Brazil, in 1990 and 2015: estimates from the global burden of disease study. Rev Bras Epidemiol 2017;20:46-60.

30 Starfield B, Shi L, Macinko J. Contribution of primary care to health systems and health. Milbank Q 2005;83:457-502.

31 WHO global health expenditure atlas, 2014. Available: http://www. who.int/about/licensing/copyright form/en/index.html

32 Carneiro VB, Oliveira PdeTR, Bastos MdoSCB, et al. Avaliação Da Mortalidade E Internações Por Condição Sensível À Atenção Primária Em Menores De 5 Anos, Antes E Durante O Programa Mais Médicos, No Marajó-Pará-Brasil. Saúde em Redes 2016;2:360-71.

33 Macinko J, Dourado I, Aquino R, et al. Major expansion of primary care in Brazil linked to decline in unnecessary hospitalization. Health Aff 2010;29:2149-60.

34 Facchini LA, Piccini RX, Tomasi E. Evaluation of the effectiveness of Primary Health Care in South and Northeast Brazil: methodological contributions]. Cad saúde pública / Ministério da Saúde, Fundação Oswaldo Cruz, Esc Nac Saúde Pública 2008;24:S159-72.

35 Asaria M, Ali S, Doran T, et al. How a universal health system reduces inequalities: lessons from England. J Epidemiol Community Health 2016;70:637-43.

36 Leal MdoC, Esteves-Pereira AP, Nakamura-Pereira M, et al. Prevalence and risk factors related to preterm birth in Brazil. Reprod Health 2016;13:127.

37 Victora CG, Aquino EML, do Carmo Leal M, et al. Maternal and child health in Brazil: progress and challenges. Lancet 2011;377:1863-76.

38 Krauer F, Riesen M, Reveiz L, et al. Zika virus infection as a cause of congenital brain abnormalities and Guillain-Barré syndrome: systematic review. PLoS Med 2017;14:e1002203-27.

39 Andrade MV, Coelho AQ, Xavier Neto M, et al. Transition to universal primary health care coverage in Brazil: analysis of uptake and expansion patterns of Brazil's family health strategy (1998-2012). PLoS One 2018;13:e0201723-11.

40 Brasileiro CN. Emenda Constitucional N95. de 15 de dezembro de 2020;2016:1-5.

41 Castro MC, Massuda A, Almeida G, et al. Brazil's unified health system: the first 30 years and prospects for the future. Lancet 2019;394:345-56. 